\title{
DECENTRALIZATION OF PUBLIC AND LOCAL AUTHORITIES IN UKRAINE
}

\author{
Lyudmila PRON'KO' ${ }^{1}$, Tatyana KOLESNIK' \\ Vinnytsia National Agrarian University, Ukraine
}

\begin{abstract}
The purpose of research is to examine the purpose of a modern system of local government in Ukraine, scientific analysis of the feasibility and benefits of implemented reforms for decentralization and subsidiary of local authorities, decentralization of public power and public control, and the need to strengthen the political status of local governments. Methodology. The methodological base for research on decentralization and local government reforms to strengthen the political status of local government and decentralization of public power is the Constitution of Ukraine, Laws of Ukraine, Decrees of the President of Ukraine, as well as publications on these issues of domestic and foreign authors. As a result (Results) study determined that according to Article 5 of the Law of Ukraine "On local government in Ukraine" The elements of local government are: local community; Village, town, city council; Village, town, city mayor; executive bodies of village, town and city councils; district (in the city) Council, created in cities with district division by the decision of the territorial community, or city council; district and regional councils, which represent common interests of territorial communities of villages, towns and cities; BSP; system of government in Ukraine is not fulfilling the role assigned to it, because there is twofold subordination and uncertainty powers of representative and executive bodies. Today there is a three-level administrative division: basic level (village, town or city), district level and level area. There is a local government council and executive body (all the decisions and programs approved by the Regional Council performed by RSA, those public authorities). Thus there is a need for continued reform of local government on the principles of decentralization and subsidiary principle because they are building the foundation of the state; One of the hallmarks of a modern democratic society has become political decentralization, the function of which is the implementation of a public authority independent of the state entities unrelated relationship of subordination. The degree of autonomy is determined that they belong to a relatively independent of the type of public authority - local government. Practical implication. Proposal reforms to decentralize power on the ground are that the three-tiered structure remains, but unlike the current situation where at district and area is under State Administration and State Administration, through amendments to the Constitution should be established district and regional executive bodies. Exist and district administration and state administration, which appointed the President of the Government's submissions. This reform should take place through changes in the Constitution; inclusion in the consideration of the bill "On public control", which will affect local governments and utility companies; strengthening political status of local governments. Value/originality. Systematic reforms in terms of priority must be given a New Constitution that guarantees enhanced political status and European standards of local government.
\end{abstract}

Key words: local government, decentralization, public authority's reform, local community, public control of local governments.

JEL Classification: P2, P25, R1, R13, R5, R51, R58

\section{Introduction}

Decentralization of power and an effective system of local government is the most important aspect of the modern state. At present proper local government is an important factor in the democratization of public life, decentralization and a prerequisite of civil society. As the example of the European Union's democratic and effective governance, Ukraine should build a viable democratic state, the legal framework which meets EU legal framework and the rule of law. For example, as the base of decentralization in France, Germany and Poland is territorial reform and decentralization, which are based on the principles of the

\footnotetext{
Corresponding author:

${ }^{1}$ Department of Administrative Management and Alternative Energy Sources, Vinnytsia National Agrarian University.

E-mail: pronkoL@ukr.net

${ }^{2}$ Department of Administrative Management and Alternative Energy Sources, Vinnytsia National Agrarian University.

E-mail: sergej.kolesnik@gmail.com
} 
Charter and the draft charter on regional self-government.

Thus, the system of local government in Ukraine needs drastic changes, regulatory, at first, material and financial, logistical and information support.

The aim of the study is to examine the current system of local government in Ukraine, scientific analysis of the feasibility and benefits of implemented reforms for decentralization and subsidiary of local authorities, decentralization of public power and public control, and the need to strengthen the political status of local governments.

\section{Elements of the current system of local government}

The basic laws which maintain a system of government in Ukraine is the Constitution of Ukraine, the Law of Ukraine "On Local Government" (Law of Ukraine, 1997), which passed on the basis of the "European Charter of Local Self-Government” (Law of Ukraine, 2006).

According to the Article 5 of the Law of Ukraine "On local government in Ukraine" the elements of local government are: local community; village, town, city council; village, town, city mayor; executive bodies of village, town and city councils; district (in the city) Council, created in cities with district division by the decision of the territorial community, or city council; district and regional councils, which represent common interests of territorial communities of villages, towns and cities; BSP.

According to the law, local community residents are united within living permanent villages, towns, cities that are independent administrative territorial units, or a voluntary association of residents of several villages with a single administrative centre. In other words, the territorial community may include not only the citizens of Ukraine, but also foreigners and stateless persons resident within the village, town and are, according to the Article 26 of the Constitution of Ukraine, the same rights and freedom, and perform the same duties that citizens of Ukraine, with the exceptions established by current legislation.

In paragraph 1 of the Article 6 of the Act clearly stipulates the fundamental provisions on the status of the local community. In particular, it is mentioned that territorial communities of villages, settlements, cities first is subject to local government, the main carrier of its functions and powers, which to date, unfortunately, has not acquired its actual status. All this shows the inadequacy of current public policies of local government, which should include the interests of the state, the local community and the individual.

\section{Introduction of reforms to decentralize local government}

The system of government in Ukraine is not fulfilling the role assigned to it, because there is twofold subordination and uncertainty powers of representative and executive bodies.
Today there is a three-level administrative division: basic level (village, town or city), district level and level area. There is a local government council and executive body (all the decisions and programs approved by the Regional Council performed by RSA, those public authorities). On the one hand, the council is formed in the general election; on the other hand there is executive body - the State Administration. Thus, there is a conflict between appointed and elected government. The situation is similar at the district level, where all the heads of administration by the Constitution (Law of Ukraine, 1997) are appointed by the President. By 28 December 2014 baseline had the resources to fulfil their mandate (resources coming from the state budget through the area).

Thus there is a need for continued reform of local government on the principles of decentralization and subsidiary principle (Reform concept, 2014), as they are the foundation for building the state.

The basis of this principle is the understanding and acceptance of the fact that all problems should be solved at a basic level, the central government can play a subsidiary, the subsidiary, not a subordinated role, and should give the regions the opportunity to make decisions. As you know, the regions of our country developing unevenly: someone has minerals, others - developed industry, someone agriculture and others. So the state should allow them to find their path of development and thus, at the community level, to decide how they want to develop further. Each unit of government is a legal entity, has property rights and powers delegated by the state. For which it shall have sufficient financial resources, and the state owes most of these resources to leave the field.

Currently, the law provides (Law of Ukraine, 2006), which is based on state regional program area should adopt their own local programs. Each approved program will receive Regional Development Fund (totalling three billion UAH) funds, $80 \%$ of which will be distributed evenly, and $20 \%$, respectively, to those who can no longer finance its part. Thus, the distribution mechanism Regional Development Fund becomes transparent and understandable. Previously the government determines to which region and on financing coming today law provides for the interdepartmental commission, which will be the body that coordinates the execution and implementation of programs. Locally created regional development agencies with OSA on the basis of public-private partnership (these belong to representatives of the chamber of commerce, NGOs, and local authorities). For example, in the EU (Hungary, Slovakia and Poland) to promote regional development created a separate executive agency.

Now, for the regional development of our country, the EU has allocated 55 million euro, will implement a number of small programs. If these funds are used wisely, next year you can expect a much larger amount to half a billion USD.

Proposal reforms to decentralize power on the ground are that the three-tiered structure remains, but unlike the current situation where at district and area is under 
State Administration and State Administration, through amendments to the Constitution should be established district and regional executive bodies. For example, the state council approves the executive committee during the session, as the district council will form its executive committee. Exist and district administration and state administration, which appointed the President of the Government's submissions. This reform should take place through changes in the Constitution.

As a result, local authorities will lose their atypical features - such as enforcement of regional or district council. They were left alone control function and implementation of government programs, as head of the local administration appointed by the President on the proposal of the Government. Also, the administration will coordinate the activities of executive bodies in the regions (for example, pension funds, prosecutors, and police). Rather than carry out the decisions of local governments, the administration will carry out overall control and supervision of regional and district councils.

Thus, the powers of local state administrations can be divided into: own - exercise executive functions in certain areas (software protection, orphans, etc.); coordination - coordination of territorial bodies of central executive bodies within the area and the region; Control - for control of the legality of acts of local government and the quality of local government public services.

And to the office of the district are:

- Maintenance of common property territorial community area;

- Transport infrastructure of regional importance;

- Education and training of children in boarding schools, youth sports school;

- Provision of secondary health care (medical centres, hospitals, maternity homes, etc.) (Pron'ko, 2016).

\section{Features of decentralization of public administration reform}

One of the hallmarks of a modern democratic society has become political decentralization, the function of which is the implementation of a public authority which is independent of the state entities unrelated relationship of subordination (Lupenko, 2015). The degree of autonomy is determined that they belong to a relatively independent of the type of public authority - local government. Thus, decentralization of public power implies exclusion of a self-governing part of the government formation with fixing this exclusion as in the Constitution, so (mostly) and current legislation.

The People's Deputies identify the legal and organizational basis of the right of territorial communities to participate in public control over the implementation of their rights. Public control will affect local governments and utilities.

The corresponding proposal contains a draft law "On public control”. The bill provides that public control - is the work of public control, such as full members of the territorial community, local departments of public associations and political parties, community organizations and MPs of supervision, inspection and evaluation of:

local governments;

- public enterprises, institutions and organizations;

- educational and health care, culture and social protection;

- legal and physical persons - service providers in the relevant community.

Also, this project concerns legal and physical persons that receive the local budget, as well as those whose work affects the interests of the local communities in terms of environmental pollution, fire safety, sanitaryepidemiological and radiological situation of food safety.

The activities of the mentioned bodies will be tested on the compliance of such activities with the laws of Ukraine and the interests of the local community.

The procedure for the implementation of public control should take place in a sociological and statistical research, public monitoring, assessment and verification, reporting on the work of public control, preparation and submission of proposals to local authorities on the results of public control, discussing the subject of public scrutiny at public meetings.

Reports subjects of public control of the work are available to the public without fail by their publication or public hearing.

Thus, this law will increase the openness and transparency of local government, enterprises, institutions and organizations.

Thus, the specificity of decentralization alienation of government necessitates the division of socially important needs and interests to those whose satisfaction is a function only of the state, and those, the implementation of which can be transferred to other entities. Only because of this clear separation of State may transfer to other entities of significant secondary for themselves but socially necessary functions (Lupenko, 2015). Dismissal States from these features contribute to the stabilization of the government as the practical implementation of a number of socially necessary functions close to the consumer of public services and state removed from responsibility for certain functions.

However, incorrect distribution of functions without regard to their social significance, the exercise of those or other entities to ensure implementation of the necessary resources and responsibilities may adversely affect the ordering of public life. However, one should take into account aspects under which the centralization policy is seen as the only constructive consolidating and stabilizing society.

\section{The need for reforms to strengthen the political status of local government}

The need to strengthen the political status of local government as a junior public authorities have in many scientific studies. But, clearly, this is backed up not 
only referring to the generally recognized principles of democracy and European standards, but more real facts that emphasize the effectiveness of management of decentralized power. The most convincing of these are:

1. The decentralized power provides a more efficient allocation of resources in the sector of public goods. This fact is based on the notion that these kinds of benefits depends on the needs and interests of people living in a particular area. As a result, the institutional system, in which political decisions taken at local and regional levels to make those resources, is making public option more accurate. As a result, rational policy supports particularly those development programs which promote the growth of the prestige and increase the chances of winning the next election. Thus public choice at the local level allows better meet the needs of the population in public goods and services without increasing the volume of resources.

2. Decentralization enhances the controllability of the public authorities of the local communities, as the link between taxes paid and the provision of public goods is more direct and transparent. Local politicians are more difficult to hide the inefficiency of public spending, forcing them to be more responsible in developing and implementing local policies.

3. Availability of own competence of local public authorities in forming the local tax base and the disposal of local budgets, availability of appropriate material and financial resources enables them to form an independent policy development of local communities, encourages them to reduce unjustified costs in the public sector.

Thus, hover facts make it possible to assert that the reform oflocal self-government and territorial organization of power in Ukraine is impossible without political will, which would contribute to the adoption of a significant number of laws and the will of local communities to unite. After the process of decentralization and reform of administrative and territorial structure in many European countries lasted more than 5 years, so you cannot expect instant results by adopting the necessary laws.

\section{Research methodology}

The methodological base for research on decentralization and local government reforms to strengthen the political status of local government and decentralization of public power is the Constitution of Ukraine, Laws of Ukraine, Decrees of the President of Ukraine, as well as publications on these issues of domestic and foreign authors. In this direction domestic scientists have taken a number of important steps, including the study of the theoretical foundations of government, constitutional principles of its implementation, the history of government in Ukraine, features contemporary national governments. Restructuring local government in Ukraine and Poland's experience in reforming local government investigated many Ukrainian scientists in 2013,2014,2015, respectively.

\section{Findings}

Systematic reforms in terms of priority must be given a New Constitution that guarantees enhanced political status and European standards of local government. International experience and practice show that the reform process must start building the foundation of territorial authorities to build economically capable community to reform the administrative and territorial structure.

\section{Conclusions}

So, update the constitution makes sense only if the implementation of new constitutional provisions will open the prospect of the adoption of laws necessary for optimization of the public authorities, the territorial organization of power in Ukraine, improving local governance. The implementation of these tasks is the essence of true reforms in decentralization of power and development of local self-government. They should create institutional preconditions for the implementation of various sectoral reforms.

According to many experts, the reform for Ukraine should take place in two phases: voluntary and systematic. At the current stage of voluntary adopted the Law "On voluntary association of communities", "On cooperation of local communities", "On Principles of regional policy." Systemic step is to amend the Constitution, the adoption of new laws "On Local Government", "On local state administrations" (that they were not executive bodies and supervised and coordinated state policy), "On service in local government" (to finally determine who is a civil servant in the city council).

\section{References}

Kropyvko M.F., \& Malik M.J. (2015). Integration and self-organization of the agricultural business in the decentralization of power: monograph. K.: NNC IAE, 447 p.

On ratification of the European Social Charter (revised): Law of Ukraine of 14.09.2006. Number 137-V. Retrieved from: http://zakon.rada.gov.ua

On local government in Ukraine: the Law of Ukraine of 21.05 .1997 p. Number 280/97-VR. Retrieved from: http://zakon.rada.gov.ua

On cooperation of communities: Law of Ukraine of 06.17.2014 p. Number 1508-VII. Retrieved from: http://zakon.rada.gov.ua

Pron'ko L. (2016). Decentralization of power and the beginning of local government reform in Ukraine. Economy in the context of innovation development: state and prospects: materials of International scientific-practical conference (12-13 February). Uzhgorod, p. 163-166. 
The reform concept of local self-government and territorial organization of power in Ukraine Cabinet of Ministers of Ukraine of 01.04.2014 p. Number 333-p. Retrieved from: http://zakon4.rada.gov.ua/laws/show/333-2014

The Constitution of Ukraine. 28.06 .1996 p. Retrieved from: http://zakon.rada.gov.ua

\section{Людмила ПРОНЬКО, Татьяна КОЛЕСНИК \\ ДЕЦЕНТРАЛИЗАЦИЯ ПУБЛИЧНОЙ И МЕСТНОЙ ВЛАСТИ В УКРАИНЕ}

Аннотация. Целью работы является исследование современной системы местного самоуправления в Украине, научный анализ целесообразности и преимуществ введенных реформ по децентрализации и субсидиарности местной власти, децентрализации публичной власти и публичного контроля, а также необходимость усиления политического статуса органов местного самоуправления. Методика. Методологической базой для исследования вопросов децентрализации местного самоуправления и проведения реформ по усилению политического статуса органов местного самоуправления и децентрализации публичной власти является Конституция Украины, Законы Украины, Указы Президента Украины, а также публикации по этим вопросам отечественных и зарубежных авторов. В результате исследования определено: что согласно ст.5 Закона Украины «О местном самоуправлении в Украине» к элементам системы местного самоуправления относятся: территориальная община; сельский, поселковый, городской совет; сельский, поселковый, городской голова; исполнительные органы сельского, поселкового, городского советов; районные (в городе) совета, которые создаются в городах с районным делением по решению территориальной общины или городского совета; районные и областные советы, которые представляют общие интересы территориальных общин сел, поселков, городов; органы самоорганизации населения. Система самоуправления в Украине не выполняет возложенной на нее роли, поскольку существует двойственный характер подчинения и неопределенность полномочий органов представительной и исполнительной власти. Сегодня существует трехуровневая административно-территориальная система: базовый уровень (село, поселок или город), уровень района и уровень области. Есть орган местного самоуправления облсовет и исполнительный орган (все решения и программы, утвержденные облсоветом выполняются ОГА, то есть государственной властью). Таким образом возникает необходимость продолжения реформирования системы местного самоуправления на основе децентрализации и принципа субсидиарности, поскольку они являются фундаментом строительства государства. Одной из характерных черт развития современного демократического общества стала политическая децентрализация, функцией которой является реализация определенной части публичной власти самостоятельными от государства субъектами, не связанными отношениями подчинения. Степень самостоятельности определяется тем, что они относятся к органам относительно самостоятельного вида публичной власти местного самоуправления. Практическое значение. Предложение реформы по децентрализации власти на местах заключается в том, что трехуровневый устройство остается, но в отличие от современной ситуации, когда на уровне района и области являются соответственно райгосадминистрации и облгосадминистрации, из-за изменений в Конституцию должны создаваться районные и областные исполнительные органы. Будут существовать и райгосадминистрации и облгосадминистрации, как представители государственной власти. Эта реформа должна состояться через изменения в Конституции. Следующим шагом есть внесения к рассмотрению законопроекта «О публичном контроле», который будет касаться органов местного самоуправления и коммунальных предприятий и усиление политического статуса органов местного самоуправления. Значение/оригинальность. Систематизация реформ с точки зрения приоритетности должна быть задана обновленной Конституции, которая бы гарантировала повышенный политический статус и европейские стандарты местного самоуправления. 